\title{
The Italian law on body donation: A position paper of the Italian College of Anatomists
}

Raffaele De Caro $^{\mathrm{a}, *, 1}$, Rafael Boscolo-Berto ${ }^{\mathrm{a}, *, 1}$, Marco Artico $^{\mathrm{b}}$, Eugenio Bertelli $^{\mathrm{c}}$, Mario Cannas $^{\mathrm{d}}$, Francesco Cappello ${ }^{\mathrm{e}}$, Guido Carpino ${ }^{\mathrm{f}}$, Sergio Castorina ${ }^{\mathrm{g}}$, Amelia Cataldi ${ }^{\mathrm{h}}$, Guido Angelo Cavaletti ${ }^{i}$, Saverio Cinti ${ }^{\mathrm{j}}$, Lucio Ildebrando Cocco ${ }^{\mathrm{k}}$, Ottavio Cremona ${ }^{\mathrm{l}}$, Enrico Crivellato $^{\mathrm{m}}$, Antonio De Luca ${ }^{\mathrm{n}}$, Mirella Falconi ${ }^{\mathrm{k}}$, Giuseppe Familiari ${ }^{\mathrm{o}}$, Gian Luca Ferri ${ }^{p}$, Francesco Fornai ${ }^{\mathrm{q}}$, Marco Gesi ${ }^{\mathrm{q}}$, Stefano Geuna ${ }^{\mathrm{r}}$, Daniele Maria Gibelli ${ }^{\mathrm{s}}$, Antonio Giordano ${ }^{t}$, Pietro Gobbi ${ }^{\mathrm{u}}$, Germano Guerra ${ }^{\mathrm{v}}$, Massimo Gulisano ${ }^{\mathrm{w}}$, Veronica Macchi ${ }^{\mathrm{a}}$, Guido Macchiarelli ${ }^{\mathrm{x}}$, Lucia Manzoli ${ }^{\mathrm{k}}$, Fabrizio Michetti ${ }^{\mathrm{y}}$, Sebastiano Miscia ${ }^{z}$, Stefania Montagnani ${ }^{\text {aa }}$, Andrea Costantino Mario Montella ${ }^{\mathrm{bb}}$, Sergio Morini ${ }^{\mathrm{cc}}$, Paolo Onori ${ }^{\mathrm{o}}$, Carla Palumbo ${ }^{\mathrm{dd}}$, Michele Papa $^{\mathrm{n}}$, Andrea Porzionato ${ }^{\mathrm{a}}$, Daniela Elena Quacci ${ }^{e e}$, Mario Raspanti ${ }^{e e}$, Mario Rendeff ${ }^{\text {, Rita Rezzani }}{ }^{g g}$, Domenico Ribatti ${ }^{\text {hh }}$, Maurizio Ripani ${ }^{\text {f }}$, Luigi Fabrizio Rodella ${ }^{g g}, 2$, Pellegrino Rossi ${ }^{\text {ii }}$, Andrea Sbarbati ${ }^{j j}$, Paola Secchiero ${ }^{k k}$, Chiarella Sforza ${ }^{s}$, Carla Stecco ${ }^{a}$, Roberto Toni ${ }^{1 l}$, Alessandro Vercelli ${ }^{\mathrm{mm}}$, Marco Vitale ${ }^{\mathrm{ll}}$, Carlo Zancanaro ${ }^{\mathrm{jj}}$, Giorgio Zauli ${ }^{\mathrm{kk}}$, Sandra Zecchi ${ }^{\mathrm{w}}$, Giuseppe Pio Anastasi ${ }^{\mathrm{nn}}$, Eugenio Gaudio ${ }^{\circ}$

\footnotetext{
a Department of Neurosciences, Institute of Human Anatomy, University of Padua, Padua, Italy

b Department of Sensory Organs, S̈apienzaÜniversity of Rome, Rome, Italy

c Department of Molecular and Developmental Medicine, University of Siena, Siena, Italy

d Department of Health Sciences, Laboratory of Human Anatomy, University of Piemonte Orientale, Novara, Italy

e Department of Biomedicine and Neurosciences and Advanced Diagnostics, University of Palermo, Palermo, Italy

${ }^{\mathrm{f}}$ Department of Movement, Human and Health Sciences, Division of Health Sciences, University of Rome F̈oro Italico; Rome, Italy

${ }^{g}$ Department of Biomedical and Technological Sciences, Section of Human Anatomy and Histology, University of Catania, Catania, Italy

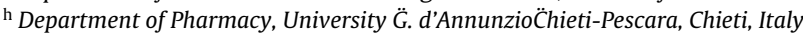

i School of Medicine and Surgery, Experimental Neurology Unit, University of Milano-Bicocca, Monza, Italy

j Department of Experimental and Clinical Medicine, Center of Obesity, Marche Polytechnic University, Ancona, Italy

${ }^{\mathrm{k}}$ Department of Biomedical and Neuromotor Sciences, University di Bologna, Bologna, Italy

${ }^{1}$ Division of Neuroscience, San Raffaele Scientific Institute, Milan, Italy

m Department of Medicine, Section of Human Anatomy, University of Udine, Udine, Italy

${ }^{n}$ Department of Mental and Physical Health and Preventive Medicine, Section of Human Anatomy, University of Campania Luigi Vanvitelli; Naples, Italy

${ }^{\circ}$ Department of Anatomical, Histological, Forensic Medicine and Orthopedics Sciences, Sapienza University of Rome, Rome, Italy

$\mathrm{p}$ Department of Biomedical Sciences, NEF-Laboratory, University of Cagliari, Cagliari, Italy

q Department of Translational Research and of New Surgical and Medical Technologies, University of Pisa, Pisa, Italy

${ }^{\mathrm{r}}$ Department of Clinical and Biological Sciences, University of Turin, Turin, Italy

${ }^{s}$ Department of Biomedical Science for Health, University of Milan, Milan, Italy

${ }^{t}$ Department of Medical Biotechnologies, University of Siena, Siena, Italy

" Department of Biomolecular Sciences, University of Urbino C̈arlo Bo; Urbino, Italy

${ }^{v}$ Department of Medicine and Health Sciences V̈incenzo Tiberio; University of Molise, Campobasso, Italy

${ }^{\mathrm{w}}$ Department of Experimental and Clinical Medicine, Anatomy and Histology Section, University of Florence, Florence, Italy

${ }^{x}$ Department of Life, Health and Environmental Sciences, University of L'Aquila, L'Aquila, Italy

y Department of Neuroscience, Università Cattolica del Sacro Cuore, Rome, Italy

${ }^{z}$ Department of Medicine and Aging Sciences, University G̈. d'AnnunzioC̈hieti-Pescara, Chieti, Italy

aa Department of Public Health, School of Medicine and Surgery, University of Naples Federico II, Naples, Italy

bb Department of Biomedical Sciences, Azienda Ospedaliero-Universitaria di Sassari, Sassari, Italy

cc Laboratory of Microscopical and Ultrastructural Anatomy, C̈ampus Bio-Medico di RomaÜniversity, Rome, Italy

dd Department of Biomedical, Metabolic and Neural Sciences, Section of Human Morphology, University of Modena and Reggio Emilia, Modena, Italy

ee Department of Medicine and Surgery, University of Insubria, Varese, Italy
}

\footnotetext{
* Corresponding authors at: Institute of Human Anatomy, Department of Neurosciences, University of Padova, Via A. Gabelli 65, Padova 35127, Italy. E-mail addresses: rdecaro@unipd.it (R. De Caro), rafael.boscoloberto@unipd.it (R. Boscolo-Berto).

1 Raffaele DE CARO and Rafael BOSCOLO-BERTO equally contributed to this work.

2 The author Luigi Fabrizio RODELLA, formerly Full Professor of Anatomy, is now passed away.
} 
ff Department of Surgery and Biomedical Sciences, Section of Human, Clinical and Forensic Anatomy, University of Perugia, Perugia, Italy

gg Department of Clinical and Experimental Sciences, Anatomy and Physiopathology Division, University of Brescia, Brescia, Italy

hh Department of Basic Medical Sciences, Neurosciences and Sensory Organs, University of Bari Medical School, Bari, Italy

ii Department of Biomedicine and Prevention, University of Rome Tor Vergata, Rome, Italy

jj Department of Neurosciences, Biomedicine and Movement Sciences, Anatomy and Histology Section, University of Verona, Verona, Italy

${ }^{\mathrm{kk}}$ Department of Morphology, Surgery and Experimental Medicine and LTTA Centre, University of Ferrara, Ferrara, Italy

${ }^{11}$ Department of Medicine and Surgery, Section of Human Anatomy, University of Parma, Parma, Italy

$\mathrm{mm}$ Department of Neuroscience Rita Levi Montalcini, University of Turin, Turin, Italy

${ }^{\mathrm{nn}}$ Department of Biomedical, Dental Sciences and Morphological and Functional Images, University of Messina, Messina, Italy

\section{A R T I C L E I N F O}

\section{Article history:}

Received 18 December 2020

Received in revised form 29 January 2021

Accepted 3 May 2021

Available online 15 June 2021

\section{Keywords:}

Body donation programme

Law

Regulation

Cadaver lab

Education

\section{A B S T R A C T}

In Italy, recent legislation (Law No. 10/2020) has tuned regulations concerning the donation of one's postmortem body and tissues for study, training, and scientific research purposes. This study discusses several specific issues to optimise the applicability and effectiveness of such an important, novel regulatory setting.

Critical issues arise concerning the learners, the type of training and teaching activities that can be planned, the position of academic anatomy institutes, the role of family members in the donation process, the time frame of the donation process, the eligibility of partial donation, or the simultaneous donation of organs and tissues to patients awaiting transplantation. In particular, a universal time limit for donations (i.e., one year) makes it impossible to plan the long-term use of specific body parts, which could be effectively preserved for the advanced teaching and training of medical students and surgeons. The abovementioned conditions lead to the limited use of corpses, thus resulting in the inefficiency of the whole system of body donation.

Overall, the donors' scope for the donation of their body could be best honoured by a more flexible and tuneable approach that can be used on a case-by-case basis.

Furthermore, it is deemed necessary to closely monitor the events scheduled for corpses in public nonacademic institutions or private enterprises. This paper presents useful insights from Italian anatomists with the hope of providing inspiration for drafting the regulations.

In conclusion, this paper focuses on the critical issues derived from the recently introduced Italian law on the donation and use of the body after death and provides suggestions to lawmakers for future implementations.

(C) 2021 Elsevier GmbH. All rights reserved.

\section{Introduction}

Practical anatomy education, which has profoundly influenced the field of medicine, is still a fundamental part of healthcare education and research at all university levels and beyond, including specialist training (Macchi et al., 2014). Despite improvements in information technology, cadaver dissection cannot be replaced in current practice by any existing and emerging substitutes, such as dummies or virtual bodies (Chan et al., 2020; De Caro et al., 2009).

However, in recent decades, the progressive reduction of economic resources devoted to public universities and the race to improve bibliometric parameters, such as impact factor and Hirsch index, for career progression have lead several academic anatomical institutes in Italy to reallocate funds intended for research and teaching activities (moving from cadaveric dissection on 'table' to laboratory research on 'bench'). Furthermore, the number of young anatomical fellows who spend part of their training learning dissection techniques has remarkably decreased over time. To date, few public universities in Italy have a working dissecting room run by anatomists with basic skills to perform teaching and research on corpses. The rising trend in expanding university courses and their attendees and the spread of cadaver labs have caused the request for an increasing number of corpses, which are only in part replaceable by anatomical parts obtained from ordinary surgical activity (Macchi et al., 2011).

Therefore, several body donation programmes have been implemented in Europe, the United States, and Asia over the last decades, and these programmes represent a significant means of supplying anatomical corpses that are available for study, training, and scientific research purposes (Porzionato et al., 2012; Riederer, 2016).
The issue of body donation has profound ethical implications and calls for irreproachable and specific regulations to avoid hurting people's feelings and prevent misleading conduct. In Italy, the legislative core reference goes back to the beginning of the last century and was later supplemented by amendments (Italian Republic, 1990; Kingdom of Italy, 1933). The Italian National Bioethics Committee harshly criticised the content of the original document (Italian National Bioethics Committee, 2013).

However, the lack of policies devoted to facilitating this liberal gesture of high moral value hindered the full maturation of donation programmes, thus decreasing the number of donations. In June 2019, a hearing on the issue was held in Rome by politicians promoting the bill. The consultation allowed the Italian College of Anatomy to expose the critical points of a system that did not favour or encourage body donation. A new law has recently been introduced after the matter had been addressed several times for more than a decade (Italian Republic, 2020). Nevertheless, some critical points remain both on the medicolegal and anatomical sides, and these issues could be theoretically resolved in the implementing regulation that is being drafted (Bolcato et al., 2020; Boscolo-Berto et al., 2020).

Following a scientific initiative by the president of the Italian College of Anatomists and despite the restrictions imposed by the COVID-19 pandemic, a working group of Italian anatomy academics was set remotely to analyse the regulations and procedures currently used in Italy for managing body donations. This effort is part of a more extensive project on body donation regulation by the authors and other anatomy academicians. Comparative, critical, and scientific studies gave rise to the present position paper, which aims to draw the international anatomic community's attention 
to the updated Italian regulatory framework, to share the principles and controversies underlying the legislation on the matter of body donation, and to draw attention to critical issues should other countries should undertake the same legislative remodelling in the future.

\section{The regulatory framework and its contradictions in Italy}

\subsection{The past}

The scientific community has long established that practice on corpses cannot be easily replaced by virtual devices or experimental animal models. Accordingly, the anatomical dissection of a human body still has paramount value in medical education and training (De Caro et al., 2009; Pan et al., 2020). The donation of one's body after death to science enables study, training, and scientific research activities that enhance anatomy education and surgical training; allows for the development of surgical techniques and the testing of new devices; and deepens medical knowledge on degenerative diseases (Larner et al., 2015). However, the limited number of body donations resulting from disinformation on the subject, the outdated regulatory framework, and the increasing number of training courses and research activities have led to a shortage of corpses worldwide (De Gama et al., 2020; Riederer et al., 2015).

In Italy, the founding principles on which the regulatory sources overlapped over time initially referred to the constitutional principles stated in articles 9 and 32, which refers to the promotion of culture and scientific and technical research with the protection of health as a fundamental individual right and a collective interest (Constituent Assembly of the Italian Republic, 1948). However, the Consolidated Law is regulated by Royal Decree No. 1592/1933 and has a twofold implication that is inconsistent with the abovementioned constitutional principles, at least in practical applications.

First, from an omissive perspective, it legitimatised the exploitation of corpses of unknown people or those with relatives or associations who did not organise a funeral or take responsibility for the transportation of the body (Kingdom of Italy, 1933).

Second, from a commissive perspective, it indirectly admitted the chance of a binding denial by relatives at the time of body delivery for scientific purposes, as later reaffirmed by the provisions of the Mortuary Police Regulations (Italian Republic, 1990).

These regulations were criticised by the Italian National Bioethics Committee because they were both defective. The Italian National Bioethics Committee invokes the principle of altruism and solidarity inspired by the donation of the body to the community for study, training, and scientific research purposes, which embody the meaning of continuity of life after death and indirectly contributes to health protection. From this perspective, body donation, which have ethical and moral implications, can only be the expression of a liberal and conscious decision that is demonstrated with the donor's informed consent (Italian National Bioethics Committee, 2013). A simple mechanism of silent assent cannot be automatically applied, thus forcing unexpressed solidarity. In the case of a donor's informed consent to body donation, its annulment by any family member with a different decision must not be allowed (Italian National Bioethics Committee, 2013). Therefore, the restrictions posed an obstacle to the implementation and operation of body donation programmes.

\subsection{The future}

Law No. 10 of 10 February 2020 entitled 'Rules regarding the disposition of one's body and postmortem tissues for study, training, and scientific research purposes' was introduced in Italy (Italian Republic, 2020) after the matter had been debated for over a decade
(Supplementary File). The law contains several normative references (Table 1) and consists of 10 articles.

\subsubsection{Article 1 - Matter of law}

1 This law lays down rules on the disposition of one's own corpse and on postmortem tissues for study, training, and scientific research purposes by subjects who have expressed their consent in life according to the formality established by article 3 .

2 The use of human corpse or postmortem tissues is inspired by the principles of solidarity and proportionality and is regulated in such a way that ensures respect for the corpse.

3 The corpse and tissues of subjects whose death has been ascertained with a certificate issued by the bodies in charge can be used in studies, trainings, and scientific research.

4 After the declaration of death, the corpse of the deceased must remain in the morgue for at least $24 \mathrm{~h}$ before being destined for study, training, and scientific research.

Although the law aims to enable the assessment, training, and scientific research of cadavers, it indirectly pays particular attention to a small group of end users, such as surgeons, who need to simulate surgical procedures on the cadaver in cadaver labs. The proposal to keep a donated body available for a single year prevents the use of conservative body treatments that allow extensive use for learning, which is typically required in an academic setting in favour of first- and second-cycle studies or a single-cycle master's degree in medicine and surgery. Therefore, donated bodies should be used shortly after obtainment, as requested by surgeons, and should be studied in cadaver labs organised for their training. However, a body used for study will not be suitable for further teaching and training activities. This leads to the limited use of the corpses, thus resulting in the inefficiency of the whole system of body donation. Therefore, the donor's memory cannot be honoured because the chance of implementing teaching and training programmes for the highest possible number of learners cannot be achieved.

Concerning ethical commitment, the use of a corpse in an anatomical room by learners and trainees for study, training, and scientific research is an opportunity for deepening the ethical aspects of body donation (Ghosh, 2015). Regrettably, students in Italy are not explicitly trained on body donation as an altruistic choice with a high moral value and social impact. These notions are currently offered on the basis of the autonomous initiative of academic anatomical institutes and represent one more commitment and use of resources, thus making such concepts further challenging in times of tight economic circumstances. Therefore, it would be appropriate to introduce lectures on specific ethical topics of interest for body donation as a broader interpretation of the obligation to provide the information required by law (McHanwell et al., 2008).

On the other hand, the law states that after the declaration of death, at least $24 \mathrm{~h}$ must elapse before the corpse can be used for scientific and training activities (Italian Republic, 2020; University of Antwerp, 2020). However, death is ascertained by the irreversible termination of all brain functions, e.g., after a prolonged cardiac arrest verified by a flat electrocardiogram lasting at a minimum of 20 min or after a devastating and definitive lesion to the whole brain documented by clinical and instrumental evaluations aimed at defining the cause of the injury, the unconscious state, the absence of all reflexes of the brain stem, and spontaneous breathing after apnoea tests, together with the lack of electrical brain activity detectable by an electroencephalogram. In the latter case, the observation could not last less than six hours for adults (Italian Republic, 1993, 1994, 2008). A shortened observation would allow for the better preservation of the anatomical parts for use in neuroanatomical and neuropathological research. 
Table 1

Normative references of Law No. 10 of 10 February 2020.

\begin{tabular}{|c|c|c|c|c|}
\hline Legal entity & Regulation & Reference & Normative matter & Permanent hyperlink \\
\hline \multirow[t]{2}{*}{ Italian Republic } & $\begin{array}{l}\text { Decree of the President } \\
\text { of the Republic }\end{array}$ & No. 285 & $\begin{array}{l}\text { Approval of the Mortuary Police } \\
\text { Regulations }\end{array}$ & $\begin{array}{l}\text { https://www.gazzettaufficiale.it/eli/id/ } \\
\text { 1990/10/12/090G0312/sg }\end{array}$ \\
\hline & & September 10, 1990 & & \\
\hline \multirow[t]{5}{*}{ Italian Republic } & Decree-law & No. 158 & $\begin{array}{l}\text { Conversion into law, with amendments, of } \\
\text { the decree-law No. } 158 \text { of September } 13 \text {, } \\
\text { 2012, containing urgent provisions to } \\
\text { promote the development of the country } \\
\text { through a higher level of health protection }\end{array}$ & $\begin{array}{l}\text { https://www.gazzettaufficiale.it/eli/id/ } \\
\text { 2012/11/10/012G0212/sg }\end{array}$ \\
\hline & & September 13, 2012, & & \\
\hline & & converted with & & \\
\hline & & modifications by the law & & \\
\hline & & $\begin{array}{l}\text { No. } 189 \text { of November } 8 \text {, } \\
2012\end{array}$ & & \\
\hline \multirow[t]{3}{*}{ Italian Republic } & Law & No. 3 & Delegation to the government on clinical & https://www.gazzettaufficiale.it/eli/id/ \\
\hline & & & $\begin{array}{l}\text { trials of drugs as well as provisions for the } \\
\text { reorganisation of the health professions } \\
\text { and for the health management of the } \\
\text { Ministry of Health }\end{array}$ & $2018 / 1 / 31 / 18 G 00019 / s g$ \\
\hline & & January 11, 2018 & & \\
\hline \multirow[t]{3}{*}{ Italian Republic } & Law & No. 400 & Discipline of government activity and & https://www.gazzettaufficiale.it/eli/id/ \\
\hline & & & $\begin{array}{l}\text { regulation of the Presidency of the Council } \\
\text { of Ministers }\end{array}$ & $1988 / 09 / 12 / 088 G 0458 / \mathrm{sg}$ \\
\hline & & August 23,1988 & & \\
\hline \multirow[t]{2}{*}{ Italian Republic } & Law & No. 184 & $\begin{array}{l}\text { Discipline of the adoption and custody of } \\
\text { minors }\end{array}$ & $\begin{array}{l}\text { https://www.gazzettaufficiale.it/eli/id/ } \\
\text { 1983/05/17/083U0184/sg }\end{array}$ \\
\hline & & May 4, 1983 & & \\
\hline \multirow[t]{3}{*}{ Italian Republic } & Legislative decree & No. 211 & Implementation of Directive 2001/20/EC & https://www.gazzettaufficiale.it/eli/id/ \\
\hline & & & $\begin{array}{l}\text { relating to the application of good clinical } \\
\text { practice in the conduct of clinical trials of } \\
\text { drugs for clinical use }\end{array}$ & 2003/08/09/003G0229/sg \\
\hline & & June 24, 2003 & & \\
\hline \multirow[t]{2}{*}{ Italian Republic } & $\begin{array}{l}\text { Decree of the President } \\
\text { of the Republic }\end{array}$ & No. 396 & $\begin{array}{l}\text { Regulation for the revision and } \\
\text { simplification of the civil status order }\end{array}$ & $\begin{array}{l}\text { https://www.gazzettaufficiale.it/eli/id/ } \\
\text { 2000/12/30/000G0442/sg }\end{array}$ \\
\hline & & November 3, 2000 & & \\
\hline \multirow[t]{2}{*}{ Italian Republic } & Law & No. 578 & Rules for ascertaining and certifying death & $\begin{array}{l}\text { https://www.gazzettaufficiale.it/eli/id/ } \\
\text { 1994/01/08/094G0004/sg }\end{array}$ \\
\hline & & December 29, 1993 & & \\
\hline \multirow[t]{2}{*}{ Italian Republic } & Law & No. 219 & $\begin{array}{l}\text { Rules regarding informed consent and } \\
\text { advance treatment provisions }\end{array}$ & $\begin{array}{l}\text { https://www.gazzettaufficiale.it/eli/id/ } \\
\text { 2018/1/16/18G00006/sg }\end{array}$ \\
\hline & & December 22, 2017 & & \\
\hline \multirow[t]{2}{*}{ Italian Republic } & Law & No. 205 & $\begin{array}{l}\text { State budget for the financial year } 2018 \\
\text { and multiannual budget for the three-year } \\
\text { period of } 2018-2020\end{array}$ & $\begin{array}{l}\text { https://www.gazzettaufficiale.it/eli/id/ } \\
\text { 2017/12/29/17G00222/sg }\end{array}$ \\
\hline & & December 27, 2017 & & \\
\hline \multirow[t]{2}{*}{ Kingdom of Italy } & Royal decree & No. 1592 & $\begin{array}{l}\text { Approval of the Consolidated Law on } \\
\text { Higher Education Laws }\end{array}$ & $\begin{array}{l}\text { https://www.gazzettaufficiale.it/eli/id/ } \\
\text { 1933/12/07/033U1592/sg }\end{array}$ \\
\hline & & August 31, 1933 & & \\
\hline
\end{tabular}

\subsubsection{Article 2 - Promotion of information}

1 The minister of health promotes, with respect to a free and conscious choice, information initiatives aimed at spreading the knowledge of the provisions of this law among citizens by using the resources available under current legislation for the implementation of institutional communication projects.

2 In accordance with the discipline established by the regulation referred to in article 8, the regions and local health units adopt initiatives aimed at the following:

a) Spreading of knowledge on the provisions of this law among general practitioners, family paediatricians, physicians of public or private healthcare facilities, and health care professionals.

b) Dissemination of correct information on the use of human corpse and postmortem tissues for study, medical training, and scientific research purposes among citizens via appropriate actions by municipal administrations and voluntary organisations.

The new law extends to several public institutions the role of promoting initiatives to inform the public by fostering the body donation culture with respect to a liberal and mindful choice. The awareness campaign will also employ general practitioners, family paediatricians, and physicians of public or private healthcare facilities. It will have the practical purpose of making people aware of the beneficial implications of body donation for study, training, and scientific research purposes. It will be necessary to find the most suitable approach and content to transmit this information without hurting social or religious norms.

Furthermore, it should also be emphasised that body donation for scientific and training purposes is entirely consistent with organ and tissue donations. This is a further gesture in the spirit of giving towards living people with severe illness for whom transplantation represents the last way forward for restoring health or even preserving life (Italian National Bioethics Committee, 2013). Certainly, the donated body would probably have different and lesser didactic and formative values but is coherent with the ethical conception of its priority use being already recognised and fully accepted.

\subsubsection{Article 3 - Expression of consent}

1 The act of disposing one's corpse or postmortem tissues takes place by means of a declaration of consent to the use of the same. The declaration is delivered to the settlor's Local Health Unit, 
which has the obligation to keep it and to transmit its information electronically to the database.

2 The settlor, in the declaration referred to in paragraph 1, also indicates a person who is responsible for communicating the existence of specific consent to the physician who ascertains the death; this person is hereinafter referred to as the 'trustee'. In the same declaration, the settlor can indicate a substitute for the trustee in the event of the trustee's death or supervening incapacity if these events occurred before the settlor's death or if there is objective impossibility for the trustee to perform the tasks provided for in this law promptly.

3 The trustee and his possible substitute must be of age and capable of understanding and wanting. Acceptance of the appointment by the trustee and the substitute takes place via the signing of a declaration of consent. A copy of the declaration of consent will be issued to the trustee and substitute. The trustee and substitute can withdraw their acceptance at any time via written communication to the settlor.

4 The assignment of the trustee and his substitute can be revoked by the settlor at any time in the same way as the appointment and without obligation to state the reasons for revocation.

5 The settlor can revoke consent at any time in the manner prescribed in paragraph 1 . The revocation must be communicated to the local health unit that transmitted the consent to the database referred to in paragraph 1 . In cases where reasons for emergency and urgency prevent the withdrawal of consent already expressed with the forms referred to in paragraph 1, it can be expressed with a verbal declaration collected or videotaped by a physician in the presence of two witnesses.

6 For underaged individuals, consent to the use of the corpse or postmortem tissues must be expressed in the forms referred to in paragraph 1 by both parents exercising parental responsibility, legal guardians, or foster caregivers. The revocation referred to in paragraph 5 is also expressed by one of the subjects indicated in the first sentence of this paragraph.

Fortunately, in the past decades, the logic of exploitation legitimated by the previously existing regulations has never been effectively put into practice in Italy. The Italian National Bioethics Committee criticised the alleged consent obtained according to the principle of silent assent because it did not result from the awareness of the shared ethical values underlying the body donation. Likewise, the International Federation of Associations of Anatomists (IFAA) and the European Federation for Experimental Morphology have also criticised this practice, which is still present in some countries (Ghosh, 2015; International Federation of Associations of Anatomists (IFAA), 2012; Italian National Bioethics Committee, 2013). Recently, some regions in Italy have attempted to introduce regulations that allow body donation despite the limits imposed by previous legislation. However, this attempt was unsuccessful owing to opposition from the State Attorney's Office (State Attorney's Office of the Italian Republic, 2019).

The new law is undoubtedly a step forward in the regulation of a long-neglected area of interest, into which the value of personal choices was not considered, particularly 'after death'. The corpse cannot be considered a mere object even though one does not deal with the person who was in life (Italian National Bioethics Committee, 2013). This is a matter of respect for personal willingness and dignity. The donation appeals to an altruistic and solidaristic principle that is evidenced by individual selfdetermination in favour of the community.

Moreover, the law provision implies a further significant ethical, albeit indirect, implication. This makes surgical experimentation on other animal species less attractive. Other animals are often used alive in procedures with limited and questionable educa- tional value because of their anatomical differences to humans (e.g., intestinal surgery in pigs) (Martini et al., 2015).

The involvement of family members in the body donation process should be encouraged. This is mainly due to the psychological meaning of such a symbolic choice and its impact on bereaved family members, who may suffer from the 'endless' feelings perceived when the corpse of their family member is not buried but donated for an unlimited amount of time (Italian National Bioethics Committee, 2013; Stroebe and Schut, 2010).

A further issue that is not considered by the recently introduced law is that some donors may be interested in restricting the donation only to some anatomical parts (e.g., brain and heart) or excluding some anatomical districts from use and dissection (e.g., face and genitals). This propensity and the belief that it is not possible to comply with such a request could limit the number of donors. Guaranteeing this binding possibility by law and respecting it would undoubtedly be an incentive for those who feel the need for it (Italian National Bioethics Committee, 2013).

\subsubsection{Article 4 - Reference centres}

1 In agreement with the minister of education, university, and research and after coming to an agreement within the permanent conference for relations between the state, regions, and autonomous provinces of Trento and Bolzano, the minister of health identifies universities; high-specialty hospitals; and the Scientific Institute for Research, Hospitalisation, and Healthcare (IRCCS) reference centres for the conservation and use of corpses for the purposes referred to in this law.

2 The activities of the reference centres, which require the use of corpses, its organs, or tissues (as stated in paragraph 1), must comply with the scientific research projects for which the territorially competent independent ethical committee has issued a favourable opinion. Surgical training activity, which is in line with the educational plan of the authorised reference centres, requires only the authorisation of the health management of the corresponding structure and does not require the opinion of the ethics committee.

The introduction of reference centres for the conservation and use of corpses for study, training, and scientific research purposes allows the concentration of activities on institutions that can live up to the task without wasting resources and skills or, even worse, tolerating a jungle of do-it-yourself services. In Italy, few centres have implemented body donation programmes (Padova, Bologna, Torino, Milano, Palermo, Roma-Sapienza, and Firenze) and only in an academic setting (Orsini et al., 2021; Porzionato et al., 2012). Among these centres, the Institute of Human Anatomy of the University of Padua has long since implemented a body donation programme with quality certification, and this institute has recently been appointed as a reference centre in Veneto (Porzionato et al., 2012; Regional Council of Veneto - Italian Republic, 2019). This national management system guarantees the acknowledgement of a public authority that is competent in the handling of cadavers and anatomical parts, which involves conservation and custody, use for scientific and training purposes, and return in dignified conditions to family members. An independent ethics committee that is territorially competent must issue a favourable opinion for using the corpse that is consistent with the proposed and developed scientific research projects or surgical training activities. To not weigh down the system, the permission granted by the health management of the local health unit will suffice if they are in line with the educational plan of the reference centre. However, it should be noted that the human anatomy institutes are not in agreement with the national or regional health services of local health units; in this case, an equivalent permission by the referent 
university director should be accepted as an alternative to what is inconsistent by law.

It is necessary to make an explicit reference to human anatomy institutes, which are only present at the academic level. Such institutes are naturally qualified for available logistics and skills to better cope with the commitment requested to the reference centres and have always been recognised as the only recipients in the management of the body for scientific purposes (Italian Republic, 1990). The expertise required to implement an efficient system for using the corpse in study, medical training, and scientific research activities is manifold and complex. They range from the reception of the body and its predisposition to storage, the assignment of the bodies for suitable activities, the conservative treatment necessary for the preparation of long-lasting prosections, and the preparation of museum educational samples. Moreover, the control of safety standards, updating of the registry, traceability of the anatomical material and its use, and quality certification of the whole process require resources, training, and devoted personnel.

An answer could hypothetically be ensured by anatomical scientific societies, which, through an ad hoc expert committee, would provide the certification of suitability for all centres with an active body donation programme and accredit institutions that are candidates for managing training events on the corpse even if it is not donated in Italy. At the same time, this would guarantee the minimum professional standards, respect for ethical principles underlying body donation, and safety requirements for scheduled activities. Overall, this is in the shared interests of the institutions, donors, and community as a whole (Champney, 2019, 2016; Champney et al., 2019). Furthermore, it is necessary to closely monitor the events scheduled for bodies in public nonacademic institutions or private enterprises. For this purpose, independent institutional review committees housed in academic reference centres can be established, with territorial competence by proximity. This would ensure both the scientific value of the event and the correct attitude towards the use of corpses. These elements are necessary to endorse the quality of content on a case-by-case basis. In this way, the whole process could be better coordinated in response to both teaching needs (without covering expenses) and training demand (often supported by sponsors) for shared and public interests that are nonaligned to a mere profit logic (Champney, 2019, 2016).

Finally, similar to other countries, the donor's right to independently choose the reference centre to which to donate his/her corpse should also be protected, in compliance with the principle of self-determination and the fiduciary relationship established during information meetings and in joining the programme (University of Antwerp, 2020).

\subsubsection{Article 5 - Establishment of the national list of reference} centres for the conservation and use of corpses

1 The national list of reference centres identified pursuant to article 4 for the conservation and use of corpses is established by the Ministry of Health.

2 The list, which can be consulted on the website of the Ministry of Health, is updated promptly to allow the physician who ascertains the death to identify the reference centre responsible for the area, to which he reports the death of the settlor.

3 The reference centre acquires the proof of the express consent by means of the database referred to in article 3 and takes the corpse after informing the settlor's local health unit.

4 The implementation of the provisions established in this article is performed within the human, instrumental, and financial resources provided by current legislation and, in any case, without new or greater burdens on public finance.
The activation and constant updating of a single list of reference centres for body donation will allow rapid feedback in favour of the physicians involved in the certification process of death. The identified and informed centre will be able to retrieve the proof of the donor's consent expressed in life via the national database. This virtuous automation will reduce the margin of error and prevent wasted time for the entire process.

\subsubsection{Article 6 - Restitution of the corpse}

1 The reference centres indicated in article 4 that have received the corpse of a person referred to in article 1 for study, training, and scientific research purposes are required to return the corpse to the family in a dignified condition within 12 months from the date of delivery.

2 The charges for the transport of the corpse from the moment of death until its return, the costs related to the burial, and the costs for any cremation are borne by the reference centres identified pursuant to article 4 within the resources allocated for research projects.

Recent legislation states that a donated body can be retained for a maximum of one year and subsequently returned to family members in a dignified condition. This is a terminological issue: what does 'dignified condition' mean? Sometimes, the return of a body in a dignified condition, such as allowing relatives to view the body, is not possible as a consequence of the activities performed according to the will of the donor. In this case, exposure of the donated body to relatives should be prevented by proposing cremation as a possible alternative and by recommending a farewell before the delivery of the corpse to the body donation centre.

Moreover, a period of one year is insufficient to match and perform most scientific and training activities. On one hand, the scheduling and arrangement times of congressional events and training courses that frequently involve international learners and teachers are not taken into account; on the other hand, the need to harmonise the teaching programmes on corpses in favour of students on the basis of needs that become evident during the academic year and in response to requests raised during the course are ignored. For example, the conservative treatment of corpses requires a substantial investment of time, money, and trained personnel. These efforts can be compensated by keeping the anatomical material available for several years in favour of many users. In this way, the memory and will of the donor would be best honoured. The Italian experience achieved directly in the field indicates that almost all donors, in the full freedom of choice granted to them, currently decide for an indefinite body donation term. The few who decide for a time limit indicates a term of three to five years. It is noteworthy that in Western countries, the granted time frames vary on average from three years in the United Kingdom and Belgium to four years in Spain, except in particular circumstances where social, ethnic, or religious beliefs limit the availability of the body to one year (De Gama et al., 2020; Park et al., 2011; United Kingdom, 2004; University of Antwerp, 2020). In Turkey, it is possible to retain prosections for 20 years and skeletal collections for up to 50 years; in France, there is no time limit for the return of the corpse (French Republic, 2000; Gurses et al., 2019). Overall, a one-year time limit is inadequate, and a period of at least three to five years could represent a sound compromise.

\subsubsection{Article 7 - The discipline of donations of money for study, training, and research purposes}

1 The use of the corpse, parts of it, or its postmortem tissues cannot be for profit.

2 Any donations of money made by private individuals for study, training, and scientific research purposes via the use of corpses or from the finalisation of research projects are intended for the 
management of the reference centres identified pursuant to article 4.

To date, there are no private companies in Italy that have running body donation programmes for direct profit via the sale of corpses or anatomic parts or for indirect profit via the disproportionate reimbursement of expenses incurred for the activity performed. Furthermore, a law has recently introduced the possibility of preventing their possible onset into the future because only universities, high-specialty hospitals, and the IRCCS can be recognised as reference centres for the conservation and use of donated corpses for study, training, and scientific research purposes. However, nothing can prevent private Italian companies from purchasing donated corpses or their anatomical parts abroad (Champney, 2016; Champney et al., 2019; Nie and Jones, 2019). Over time, several international anatomical scientific societies have harshly criticised foreign companies not because they recruit donors by ensuring coverage of transportation costs and possible cremation of the corpse but because of the large profit margins derived by the disproportionate reimbursement of expenses paid by the institutions that use the material worldwide for teaching and training (American Association of Anatomists (AAA), 2018; American Association of Clinical Anatomists (AACA), 2017; International Federation of Associations of Anatomists (IFAA), 2012). Likewise, private entities that organise and manage training courses for healthcare professionals in Italy can obtain substantial profits from their activities, i.e., outside the body donation process and conservation and use of corpses regulated by the recently introduced law, there is a grey area in which private companies can independently conduct their parallel business on corpses donated abroad and on purchased bodies. Rules do not regulate this activity at all, and one wonders how their practices, the quality of events, the respect for ethical principles, the dignity of the corpses, and the adequacy of the educational programme for learners can be supervised so that the anatomical material is not wasted and so that training efficiency is maximised. In this regard, it would be appropriate to introduce a supervisory authority to guarantee the principle of transparency and fairness; in the eyes of the community, everything occurs within the broader project of the use of corpses for science regardless of its origin. In line with this expected rigour, the chance of direct or indirect profit via the disproportionate reimbursement of the expenses incurred by the organisers of these events should be prevented while simultaneously avoiding the possibility for teachers and sponsors to profit from their role. This would prevent training courses that use corpses from becoming an opportunity for economic speculation. The possible establishment of foundations and nonprofit organisations with participation or patronage of universities could be a useful and functional approach for supporting study, training, and scientific research activities without profit aims.

\subsubsection{Article 8 - Implementing regulation}

1 Within three months from the date of entry into force of this law, with regulation to be adopted, we

a) establish the methods and times, in any case not exceeding 12 months, for the conservation, for the request, for transport, for the use and for the return of the corpse in a dignified condition to the family by the reference centres of which in article 4 , providing that the corpses for which the family they belong to does not request restitution can be buried, as well as the procedures for communication between the civil registrar and the reference centres;

b) indicate the reasons for excluding the use of the corpses for the purposes referred to in this law;

c) provide for connections with the civil status system; and d) establish the discipline of the initiatives provided in article 2, paragraph 2.

The implementation of regulations to which the law refers to has not yet been issued. This is an opportunity to (at least partially) rectify and better define the controversial aspects of the present study. However, one wonders how the implementing regulations can be used to correct a law that has already expressed itself in a peremptory way on some problems without leaving room for a declination that allows their correction. Technically, implementing a regulation is a provision subsequent to the promulgation of the law calling for it. It finalises its provisions and perfects its regulatory significance. It has been adopted by the Presidency of the Council of Ministers within three months since the promulgation of the law. However, it is not a binding term, and there are known cases of laws in which the implementing regulations were never adopted. This circumstance renders the original law-making useless and inapplicable in practice.

\subsubsection{Article 9 - Financial provisions}

1 The implementation of this law must not result in new or higher burdens on public finance. Public institutions that are interested in the relative implementation of this law should provide it with only the human, financial, and instrumental resources available under current legislation.

This study raises two issues. The first issue concerns the provision that several new centres will be created; this implies significant initial costs for starting the activity with regard to personnel, training, logistics of support, cold rooms, etc. It is unthinkable that everything can be established with 'zero economic balance', i.e., without precise financial allocations aimed at establishing a dedicated centre where before there was nothing. This plan would be a mere dream. Furthermore, the coverage of costs for the transport and burial or cremation of corpses is provided by the resources allocated for research projects managed by the reference centres. This leads to the transfer of resources from the field of research to logistics, and centres that have an active role in body donation will incur economic losses. The second issue concerns the practical effects of the recently introduced law, which could theoretically result in a significant increase in body donations, as observed in other European countries. In the Netherlands, requests for body donation have increased over time to the point that the country needs to halt the recruitment of donors to prevent overloading the morgues of anatomy institutes. From this desirable and fearful perspective, it will be necessary to foresee the management approach to a possible surplus of corpses by defining whether it is possible to refuse a donation, assessing whether the network of reference centres will have to face together the absorption of the offer, and identifying who will cover the additional transport costs to distant reference centres (Bolt et al., 2012).

\subsubsection{Article 10 - Repeal}

1 Article 32 of the consolidated text of the higher education laws, referred to in Royal decree No. 1592 of 31 August 1933, is repealed.

Royal decree No. 1592/1933 states that 'All corpses from hospitals are subjected to clinical autopsy. The corpses (omissis) whose transport is not done at the expense of the relatives included in the family group up to the sixth degree or by confraternities or associations that may have undertaken commitments for funeral transport of the associates and those coming from the medicolegal investigations (excluding suicides) that are not requested by relatives included in the said family group, are reserved for teaching and scientific investigations' (Kingdom of Italy, 1933). 
Consistent with the criticisms of the Italian National Bioethics Committee, the logic of exploitation of the corpse of unknown identity or of people whose family relationships and friendships vanished as enshrined in this article was finally suppressed. Therefore, the principle of self-determination of the individual prevails via the liberal expression of a conscious will inspired by the values of solidarity and altruism and addressed to the community to which the donor belonged in life (Italian National Bioethics Committee, 2013).

\section{Conclusion and future perspectives}

At the end of a debate that lasted over a decade, Law No. 10 of 10 February 2020 entitled 'Rules regarding the disposition of one's body and postmortem tissues for study, training, and scientific research purposes' was introduced in Italy. It represents the effort to regulate a sensitive and manifold issue to allow for body donation and its use for study, training, and scientific research purposes on the basis of respect for the corpse. However, the provisions only partially clarify the principles of fulfilment, limits, and control envisaged for these activities. Critical issues arise concerning the learners, the type of training and teaching activities that can be planned, the position of the academic anatomy institutes, the role of family members in the donation process, the duration of the donation, the eligibility of partial donation, or the simultaneous donation of organs and tissues to patients awaiting transplantation.

These uncertainties and interpretative weaknesses can still be addressed because the implementation regulations required by law have not yet been approved. This paper is intended to continue the constructive discussion on the topic so that the promulgated law could be improved to meet the needs of the reality it intends to regulate.

Simultaneously, the Italian community of anatomists must address all the issues that have led to a decrease in the number of centres performing anatomical dissections for the benefit of medical students and residents. Is it possible to reverse this trend? In addition to the changes called upon for this law and the increase in public funds reserved for anatomical training, what else is needed? What can Italian anatomists do in the meantime? Could it be useful to create networks on a geographical basis to bring people and resources together with the aim of creating synergies between centres in sharing what still few universities can afford? However, which approach is essential for anatomical training? Our community must make all possible efforts on several fronts to not neglect an aspect of medical education that represents, for known historical reasons, a point of pride and merit of Italian medical culture.

\section{Ethical statement}

Not applicable. The work does not involve the use of animal or human subjects.

\section{Funding}

This research did not receive any specific grant from funding agencies in the public, commercial, or not-for-profit sectors.

\section{Competing interest}

All authors declare that they have no competing financial interests or personal relationships that could have influenced the work reported in this paper.

\section{CRediT authorship contribution statement}

Raffaele De Caro: Conceptualization, Methodology, Writing original draft, Writing - review \& editing, Supervision, Project administration. Rafael Boscolo-Berto: Conceptualization, Writing - original draft, Writing - review \& editing, Project administration. Marco Artico: Writing - review \& editing. Eugenio Bertelli: Writing - review \& editing. Mario Cannas: Writing - review \& editing. Francesco Cappello: Writing - review \& editing. Guido Carpino: Writing - review \& editing. Sergio Castorina: Writing review \& editing. Amelia Cataldi: Writing - review \& editing. Guido Angelo Cavaletti: Writing - review \& editing. Saverio Cinti: Writing - review \& editing. Lucio Ildebrando Cocco: Writing - review \& editing. Ottavio Cremona: Writing - review \& editing. Enrico Crivellato: Writing - review \& editing. Antonio De Luca: Writing - review \& editing. Mirella Falconi: Writing - review \& editing. Giuseppe Familiari: Writing - review \& editing. Gian Luca Ferri: Writing - review \& editing. Francesco Fornai: Writing - review \& editing. Marco Gesi: Writing - review \& editing. Stefano Geuna: Writing - review \& editing. Daniele Maria Gibelli: Writing - review \& editing. Antonio Giordano: Writing - review \& editing. Pietro Gobbi: Writing - review \& editing. Germano Guerra: Writing review \& editing. Massimo Gulisano: Writing - review \& editing. Veronica Macchi: Writing - original draft, Writing - review \& editing, Project administration. Guido Macchiarelli: Writing - review \& editing. Lucia Manzoli: Writing - review \& editing. Fabrizio Michetti: Writing - review \& editing. Sebastiano Miscia: Writing - review \& editing. Stefania Montagnani: Writing - review \& editing. Andrea Costantino Mario Montella: Writing - review \& editing. Sergio Morini: Writing - review \& editing. Paolo Onori: Writing - review \& editing. Carla Palumbo: Writing - review \& editing. Michele Papa: Writing - review \& editing. Andrea Porzionato: Writing - original draft, Writing - review \& editing, Project administration. Daniela Elena Quacci: Writing - review \& editing. Mario Raspanti: Writing - review \& editing. Mario Rende: Writing - review \& editing. Rita Rezzani: Writing - review \& editing. Domenico Ribatti: Writing - review \& editing. Maurizio Ripani: Writing - review \& editing. Luigi Fabrizio Rodella: Writing - review \& editing. Pellegrino Rossi: Writing - review \& editing. Andrea Sbarbati: Writing - review \& editing. Paola Secchiero: Writing review \& editing. Chiarella Sforza: Writing - review \& editing. Carla Stecco: Writing - original draft, Project administration. Roberto Toni: Writing - review \& editing. Alessandro Vercelli: Writing review \& editing. Marco Vitale: Writing - review \& editing. Carlo Zancanaro: Writing - review \& editing. Giorgio Zauli: Writing - review \& editing. Sandra Zecchi: Writing - review \& editing. Giuseppe Pio Anastasi: Writing - review \& editing. Eugenio Gaudio: Writing - review \& editing.

\section{Acknowledgements}

The authors wish to sincerely thank those who donated their bodies to science so that anatomical research could be performed. The results of such research can potentially improve patient care and increase the overall knowledge of mankind. Therefore, these donors and their families deserve the highest gratitude.

We would also like to give our gratitude and respects to Prof. Luigi Fabrizio Rodella, our colleague and friend. After helping write this paper, he passed away in September 2020. He graduated with degrees in biological sciences and medicine and surgery. At the culmination of the academic track, he was appointed as a full professor of human anatomy in the Department of Clinical and Experimental Sciences, Anatomy and Physiopathology Division, University of Brescia. He headed the Postgraduate School of Sports Medicine and the degree course of Medicine and Surgery and promoted anatom- 
ical dissection courses for physicians and medical residents. He was an example of moral integrity and intellectual honesty. He will forever be in the thoughts of the Italian College of Anatomists.

\section{Appendix A. Supplementary data}

Supplementary material related to this article can be found, in the online version, at doi:https://doi.org/10.1016/j.aanat.2021. 151761.

\section{References}

American Association of Anatomists (AAA), URL https://www.anatomy.org/AAA/ About-AAA/What-Is-Anatomy/Body-Donation-Discussion.aspx Accessed April 10th, 2020 2018. A Discussion on Body Donation [WWW Document].

American Association of Clinical Anatomists (AACA), URL https://clinical-anatomy. org/images/downloads/\%0Adraft_aaca_bp_asc_.pdf Accessed April 10th, 2020 2017. Best Practices Guide for Donation Programs [WWW Document].

Bolcato, V., Braga, P., Bini, G., Belli, G, Quaiotti, J., Tronconi, L, Osculati, A, 2020. Corpses against science death: new Italian law titled "Rules relating to the directives of one's body and tissues post-mortem for study, training, and scientific research purposes". Ann. Anat. 233, 151595, http://dx.doi.org/10.1016/j.aanat. 2020.151595.

Bolt, S., Eisinga, R., Altena, M., Venbrux, E., Gerrits, P., 2012. Over my dead body: body donation and the rise in donor registrations in the Netherlands. Omega 66, 57-77, http://dx.doi.org/10.2190/OM.66.1.d.

Boscolo-Berto, R., Porzionato, A., Stecco, C., Macchi, V., De Caro, R., 2020. Body donation in Italy: lights and shadows of law No. 10/2020. Clin. Anat. 33, 950-959, http://dx.doi.org/10.1002/ca.23623.

Champney, T.H., 2016. The business of bodies: ethical perspectives on for-profit body donation companies. Clin. Anat. 29, 25-29, http://dx.doi.org/10.1002/ca.22643.

Champney, T.H., 2019. A bioethos for bodies: respecting a priceless resource. Anat. Sci. Educ. 12, 432-434, http://dx.doi.org/10.1002/ase.1855.

Champney, T.H., Hildebrandt, S., Gareth Jones, D., Winkelmann, A., 2019. BODIES R US: ethical views on the commercialization of the dead in medical education and research. Anat. Sci. Educ. 12, 317-325, http://dx.doi.org/10.1002/ase.1809.

Chan, W.C.H., Chan, S.O., Wong, A.L.Y., Ng, P.K.L., 2020. Understanding family involvement in body donation in Hong Kong: a qualitative study of registered donors and bereaved family members. Heal. Soc. Care Community 28, 270-278, http://dx.doi.org/10.1111/hsc.12861.

Constituent Assembly of the Italian Republic, 1948. Constitution of the Italian republic. Ital. Const. (January 1st).

De Caro, R., Macchi, V., Porzionato, A., 2009. Promotion of body donation and use of cadavers in anatomical education at the University of Padova. Anat. Sci. Educ. 2, 91-92, http://dx.doi.org/10.1002/ase.69.

De Gama, B.Z., Jones, D.G., Bhengu, T.T., Satyapal, K.S., 2020. Cultural practices of the Zulu ethnic group on the body and their influence on body donation. Anat. Sci. Educ. 13 (6), 721-731, http://dx.doi.org/10.1002/ase.1950.

French Republic, Decree No. 318 April 9th 2000. General Code of Local and Regional Authorities - Article R2213-13 Amended by Decree No. 121/2011.

Ghosh, S.K., 2015. Human cadaveric dissection: a historical account from ancient Greece to the modern era. Anat. Cell Biol. 48, 153-169, http://dx.doi.org/10. 5115/acb.2015.48.3.153

Gurses, I.A., Ertas, A., Gurtekin, B., Coskun, O., Uzel, M., Gayretli, O., Demirci, M.S., 2019. Profile and motivations of registered whole-body donors in Turkey: Istanbul university experience. Anat. Sci. Educ. 12, 370-385, http://dx.doi.org/10. 1002/ase.1849.

International Federation of Associations of Anatomists (IFAA), 2012. Recommendations of good practice for the donation and study of human bodies and tissues for anatomical examination [WWW Document]. Newsl. IFAA (January 1-4), Accessed April 10, 2020 http://www.ifaa.net/wp-content/uploads/2017/ 09/IFAA-guidelines-220811.pdf.

Italian National Bioethics Committee, 2013. Body donation for scientific research [WWW Document]. Pres. Counc. Minist. Opin., 1-14, URL http://bioetica. governo.it/media/3241/p109_2013_body-donation_en.pdf. Accessed April 10th, 2020.
Italian Republic, Decree Pres. Repub. No. 285 September 10th 1990. Approval of the Mortuary Police Regulations.

Italian Republic, Law No. 578 December 29th 1993. Rules for Ascertaining and Certifying Death.

Italian Republic, Decree Minist. Heal. No. 582 August 22nd 1994. Regulation Containing the Methods for Ascertaining and Certifying Death.

Italian Republic, Decree Minist. Heal. No. 136 April 11th 2008. Update of the Decree No. 582 of August 22nd, 1994, Relating to the "Regulations Containing the Modalities for Ascertaining and Certifying Death."

Italian Republic, Law No. 10 February 10th 2020. Rules Regarding the Disposition of One's Body and Post-mortem Tissues for Study, Training, and Scientific Research Purposes.

Kingdom of Italy, R. decree No. 1592 August 31st 1933. Approval of the Consolidated Law on Higher Education Laws.

Larner, S.P., McQuone, B., Schober, J.M., Loukas, M., Terrell, M., 2015. Perceptions of the living dead: an assessment of knowledge and opinions about whole body donation, its process, and willingness to become cadaveric donors in Pennsylvania. Clin. Anat. 28, 442-448, http://dx.doi.org/10.1002/ca.22516.

Macchi, V., Porzionato, A., Stecco, C., Tiengo, C., Parenti, A., Cestrone, A., De Caro, R., 2011. Body parts removed during surgery: a useful training source. Anat. Sci. Educ. 4, 151-156, http://dx.doi.org/10.1002/ase.218.

Macchi, V., Porzionato, A., Stecco, C., De Caro, R., 2014. Evolution of the anatomical theatre in Padova. Anat. Sci. Educ., http://dx.doi.org/10.1002/ase.1447.

Martini, M., Penco, S., Baldelli, I., Biolatti, B., Ciliberti, R., 2015. An ethics for the living world: operation methods of Animal Ethics Committees in Italy. Ann. Ist. Super. Sanita 51, 244-247, http://dx.doi.org/10.4415/ANN_15_03_13.

McHanwell, S., Brenner, E., Chirculescu, A., Drukker, J., van Mameren, H., Mazzotti, G., Pais, D., Paulsen, F., Plaisant, O., Caillaud, M., Laforet, E., Riedere, B., Sanudo, J., Bueno-Lopez, J., Donate-Oliver, F., Sprumont, P., Teofilovski-Parapid, G., Moxham, B., 2008. The legal and ethical framework governing body donation in Europe: a review of current practice and recommendations for good practice. Eur. J. Anat. 12, 1-24

Nie, J.-B., Jones, D.G., 2019. Confucian ethics on the commercial use of human bodies and body parts: Yi (Righteousness) or/and Li (Profit)? Anat. Sci. Educ. 12, 444-453, http://dx.doi.org/10.1002/ase.1876.

Orsini, E., Quaranta, M., Ratti, S., Mariani, G.A., Mongiorgi, S., Billi, A.M., Manzoli, L., 2021. The whole body donation program at the university of Bologna: a report based on the experience of one of the oldest university in Western world. Ann. Anat. 234, 151660, http://dx.doi.org/10.1016/j.aanat.2020.151660.

Pan, S.-Q., Chan, L.K., Yan, Y., Yang, X., 2020. Survey of gross anatomy education in China: the past and the present. Anat. Sci. Educ., http://dx.doi.org/10.1002/ase. 1952.

Park, J.-T., Jang, Y., Park, M.S., Pae, C., Park, J., Hu, K.-S., Park, J.-S., Han, S.-H., Koh, K.S., Kim, H.-J., 2011. The trend of body donation for education based on Korean social and religious culture. Anat. Sci. Educ. 4, 33-38, http://dx.doi.org/10.1002/ ase.198.

Porzionato, A., Macchi, V., Stecco, C., Mazzi, A., Rambaldo, A., Sarasin, G., Parenti, A. Scipioni, A., De Caro, R., 2012. Quality management of body donation program at the University of Padova. Anat. Sci. Educ. 5, 264-272, http://dx.doi.org/10.1002 ase. 1285

Regional Council of Veneto - Italian Republic, Delib. Veneto Reg. Counc. No. 245 March 8th 2019. Identification of the Reference Center for the Veneto Region for the Conservation and Use of Donated Bodies.

Riederer, B.M., 2016. Body donations today and tomorrow: what is best practice and why? Clin. Anat. 29, 11-18, http://dx.doi.org/10.1002/ca.22641.

Riederer, B.M., Bueno-López, J.L., Ayer, R., Reblet, C., Cadas, H., Puyal, J.P., 2015. Practical teaching of preclinical anatomy. Eur. J. Anat. 19, 205-213.

State Attorney's Office of the Italian Republic, 2019. Application for constitutional legitimacy No. 56. Off. J. - Const. Court Spec. Ser. (May 7th).

Stroebe, M., Schut, H., 2010. The dual process model of coping with bereavement: a decade on. OMEGA - J. Death Dying 61, 273-289, http://dx.doi.org/10.2190/OM. 61.4.b.

United Kingdom, 2004. Human Tissue Act 2004 (Commencement No. 5 and Transitional Provisions) Order 2006. Statut. Instrum., No. 1997 July 20th.

University of Antwerp, URL https://www.uantwerpen.be/images/uantwerpen/ container2146/files/body_donation/frequently_asked_questions_body_ donation.pdf Accessed May 14th, 2020 2020. Body Donation: Frequently Asked Questions [WWW Document]. 